\title{
The two-hit hypothesis for neuroinflammation: role of exogenous ATP in modulating inflammation in the brain
}

\author{
Bernd L. Fiebich ${ }^{1}$, Shamima Akter ${ }^{2}$ and Ravi Shankar Akundi ${ }^{*}$ \\ 1 Department of Psychiatry and Psychotherapy, Neurochemistry Research Laboratory, University of Freiburg Medical School, Freiburg, Germany \\ ${ }^{2}$ Neuroinflammation Research Laboratory, Faculty of Life Sciences and Biotechnology, South Asian University, New Delhi, Delhi, India
}

\author{
Edited by: \\ Rosanna Parlato, UIm University, \\ Germany \\ Reviewed by: \\ Hermona Soreq, The Hebrew \\ University of Jerusalem, Israel \\ Mohamed Jaber, University of \\ Poitiers, France \\ *Correspondence: \\ Ravi Shankar Akundi, \\ Neuroinflammation Research \\ Laboratory, Faculty of Life Sciences \\ and Biotechnology, South Asian \\ University, Akbar Bhawan, \\ Chanakyapuri, New Delhi-110021, \\ Delhi, India \\ e-mail: ravi.shankar@sau.ac.in
}

Brain inflammation is a common occurrence following responses to varied insults such as bacterial infections, stroke, traumatic brain injury and neurodegenerative disorders. A common mediator for these varied inflammatory responses is prostaglandin $E_{2}$ $\left(\mathrm{PGE}_{2}\right)$, produced by the enzymatic activity of cyclooxygenases (COX) 1 and 2. Previous attempts to reduce neuronal inflammation through COX inhibition, by use of nonsteroidal anti-inflammatory drugs (NSAIDs), have met with limited success. We are proposing the two-hit model for neuronal injury -an initial localized inflammation mediated by PGE $_{2}$ (first hit) and the simultaneous release of adenosine triphosphate (ATP) by injured cells (second hit), which significantly enhances the inflammatory response through increased synthesis of $P G E_{2}$. Several evidences on the role of exogenous ATP in inflammation have been reported, including contrary instances where extracellular ATP reduces inflammatory events. In this review, we will examine the current literature on the role of P2 receptors, to which ATP binds, in modulating inflammatory reactions during neurodegeneration. Targeting the P2 receptors, therefore, provides a therapeutic alternative to reduce inflammation in the brain. $\mathrm{P} 2$ receptor-based anti-inflammatory drugs (PBAIDs) will retain the activities of essential COX enzymes, yet will significantly reduce neuroinflammation by decreasing the enhanced production of $\mathrm{PGE}_{2}$ by extracellular ATP.

Keywords: ATP, microglia, neuroinflammation, NSAIDs, P2 receptors, PBAIDs, prostaglandin E2

\section{INFLAMMATION WITHIN THE BRAIN}

Various environmental factors can lead to inflammation within the brain. These range from bacterial infections that cause acute inflammation to neurodegenerative disorders that mediate chronic inflammation. The inflammation may be restricted to a local region in focal ischemia or occur in a wider zone during traumatic brain injury. Inflammation could also result from an autoimmune response such as multiple sclerosis or in response to toxins and nerve agents (for general reviews, see Lucas et al., 2006; Aguzzi et al., 2013). Recent reports implicate inflammation contributing to the pathology of psychiatric disorders such as stress, depression and schizophrenia (Najjar et al., 2013), in metabolic syndromes such as obesity and type 2 diabetes (Purkayastha and Cai, 2013), and even as a response to increased neuronal activity (Xanthos and Sandkuhler, 2014). Irrespective of the type of inflammation, the molecular mediators are oftentimes the same -prostaglandin $\mathrm{E}_{2}\left(\mathrm{PGE}_{2}\right)$ or cytokines such as interleukin-1 $\beta$

Abbreviations: AD, Alzheimer's disease; ALS, amyotrophic lateral sclerosis; ATP, adenosine triphosphate; COX, cyclooxygenase; IL-1 $\beta$, interleukin- $1 \beta$; IRF8, interferon regulatory factor 8; LPS, lipopolysaccharide; MCP1, monocyte chemotactic protein 1; MMP-9, matrix metalloproteinase 9; NSAIDs, non-steroidal anti-inflammatory drugs; PARP, poly (ADP-ribose) polymerase; PBAIDs, P2 receptor-based anti-inflammatory drugs; $\mathrm{PGE}_{2}$, prostaglandin $\mathrm{E}_{2}$; PD, Parkinson's disease; TNF- $\alpha$, tumor necrosis factor $\alpha$; UTP, uridine triphosphate.
(IL-1 $\beta)$, produced by the activity of resident microglial cells. Despite brain inflammation playing such a major role in various CNS disorders, successful therapeutic strategies to overcome it are still lacking.

$\mathrm{PGE}_{2}$ is produced by the action of cyclooxygenases (COX) which mediate the first committing step in its synthesis from arachidonic acid (Akundi et al., 2005). The constitutively active COX-1 isoform is believed to be responsible for the majority of $\mathrm{PGE}_{2}$ formed in the body. However, it is the growth factor-, cytokine- or mitogen-inducible COX-2 that emerged as the isoform responsible for the massive release of $\mathrm{PGE}_{2}$ during inflammation of all types-systemic, central, acute or chronic. The COX enzymes have been a therapeutic target in a multitude of disorders, ranging from fever and pain to cancer, rheumatoid arthritis, and Alzheimer's disease (AD; Yedgar et al., 2007). Their importance can be judged from the widespread use of aspirin as an analgesic and antipyretic; and the promise of nonsteroidal anti-inflammatory drugs (NSAIDs) against spreading neurodegeneration in AD (Szekely and Zandi, 2010). However clinical trials failed to not only halt the progression of dementia in AD patients but also showed increased risks of myocardial infarction and stroke (Jüni et al., 2004). An essential lesson learnt from the debacle of NSAIDs was that the two isoforms of COX do not functionally substitute one another but each remains indispensable in certain 
functions. COX-2 stands on a delicate balance-the neuronal isoform plays an important role in synaptic plasticity, memory consolidation and cortical development while the microglial isoform mediates neuroinflammation. Targeting COX enzymes, therefore, requires a careful consideration of the benefit-to-risk ratio.

\section{NEUROINFLAMMATION: A TWO-HIT MODEL}

An interesting observation in the past decade and half showed that the inflammatory response of microglia - the release of mature IL-1 $\beta$ from lipopolysaccharide (LPS)-primed cells_could be significantly modulated with the addition of exogenous adenosine triphosphate (ATP; Ferrari et al., 1997). More diversified studies showed that ATP is able to mediate the release of $\mathrm{PGE}_{2}$ in IL-1 $\beta$-treated astrocytes (Xu et al., 2003) or in LPS-activated macrophages (Barberà-Cremades et al., 2012). We found a similar synergistic effect of ATP on LPS-mediated PGE 2 release in primary rat microglial cells (unpublished observation). These studies conclusively showed that exogenous ATP significantly modulates inflammation. In this review, we are proposing the two-hit model for neuroinflammation. The first hit is the injury itself-nerve injury, bacterial infections, hypoxiaischemia, autoimmune reactions or proteopathies associated with neurodegeneration-leading to the activation of glial cells (Figure 1). The second hit is the release of large pools of cytosolic ATP from damaged neurons into the extracellular milieu, in response to direct injury or following glial cell activation. This excess ATP, despite mechanisms regulating their concentration outside the cell, activates a wide variety of purinergic receptors present on cells in the vicinity, thus modulating glial activity and neuronal response to inflammation. Such a model was earlier proposed for the release of mature IL- $1 \beta$ following bacterial infections (Ferrari et al., 2006). Identifying the pro-inflammatory receptors of ATP, and targeting them pharmacologically, will significantly diminish the dramatic release of prostanoids and cytokines to clinically manageable levels; thus, balancing their functional roles in active defence and tissue repair.

\section{ATP: THE COMMON DENOMINATOR FOR VARIED INFLAMMATORY INSULTS}

Both healthy neurons and glial cells carry ATP, in millimolar concentrations, within presynaptic vesicles and granules, respectively (Abbracchio et al., 2009). Neuronal ATP serves as a neurotransmitter while astrocytic ATP allows distant astrocytes to communicate with each other and modulate neuronal response. However, the release of ATP by neurons or astrocytes is usually very low, in the nanomolar range. Furthermore, the extracellular concentration of ATP is dependent on the regional distribution and local activity of synaptic ectonucleotidases CD28/CD39 which convert ATP to ADP and AMP, CD73 which converts AMP to adenosine, and nucleoside diphosphate kinase whose transphosphorylating activity maintains the exogenous levels of various nucleotides in steady state (Lazarowski et al., 2003). This steady state balance is, however, disrupted during pathological conditions when damaged neurons and chronically activated glial cells release dramatic levels of ATP, uridine triphosphate (UTP) and other intracellular nucleotides.

Not only neuropathological conditions even systemic inflammation leads to an increase in exogenous ATP within the CNS (Gourine et al., 2007). In fact the release of ATP in response to tissue injury is a universal phenomenon also seen in plants at sites of physical wounding (Choi et al., 2014). Efflux of ATP into the extracellular space is a common universal "stress signal", leading to the evolution of receptors for ATP to recognize this "danger" and initiate a stress response. Mammals evolved purinergic receptors with varying specificities for ligands such as ATP, ADP, UTP, UDP, UDP-sugars or adenosine, and diverse range of intracellular signaling mechanisms downstream to receptor activation. Nucleotides act on $\mathrm{P} 2$ receptors, with seven ionotropic P2X receptors gating $\mathrm{Na}^{+}, \mathrm{K}^{+}$, and especially $\mathrm{Ca}^{2+}$

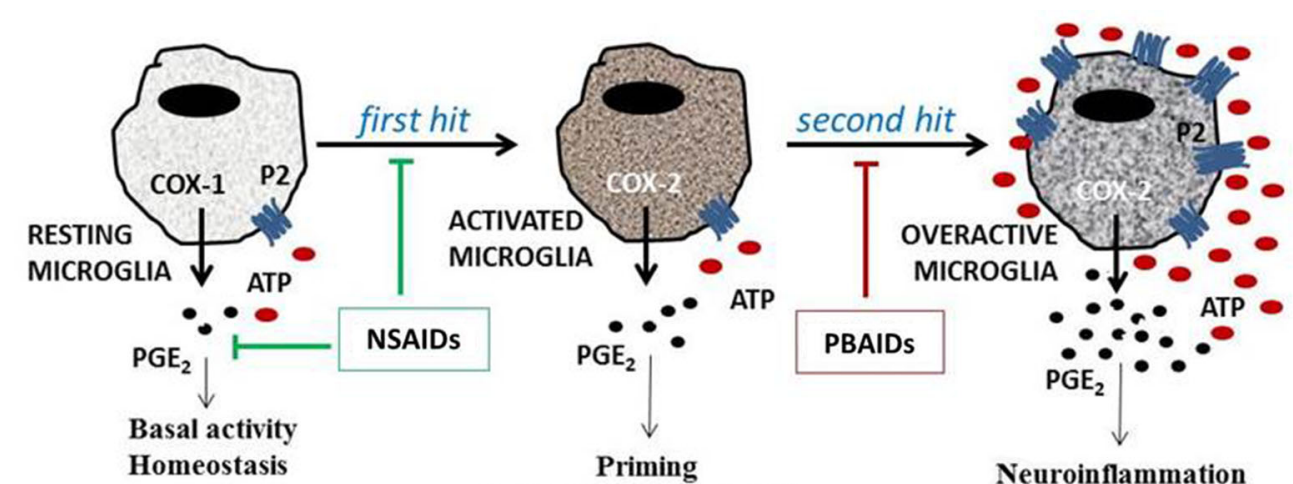

(pre-neuroinflammation)

FIGURE 1 | The two-hit model of neuroinflammation. The ATP-mediated enhancement of neuroinflammation can be explained through the two-hit model. A variety of insults, such as bacterial LPS, various cytokines, or amyloid peptides, can act as the first hit, resulting in microglial activation, COX-2 induction and $\mathrm{PGE}_{2}$ release. The second hit, following neuronal injury, death or persistent glial cell activation, results in the release of ATP, which acts on both neuronal and glial P2 receptors, leading to enhanced microglial $\mathrm{PGE}_{2}$ release. NSAIDs target COX enzymes affecting the housekeeping roles of $P G E_{2}$. ATP potentiates the effects of first hit multi-fold, and thus, would be the most relevant target for therapeutic intervention. By acting on P2 receptors, $\mathrm{PBAIDs}$ are believed to reduce $\mathrm{PGE}_{2}$ to pre-inflammatory levels without affecting the activity of COX enzymes. 
ions, and eight $\mathrm{G}$ protein-coupled metabotropic P2Y receptors (Abbracchio et al., 2009). Adenosine, on the other hand, acts on adenosine receptors, of which $A_{1}$ and $A_{3}$ adenosine receptors inhibit, while $\mathrm{A}_{2 \mathrm{~A}}$ and $\mathrm{A}_{2 \mathrm{~B}}$ adenosine receptors stimulate adenylyl cyclase (Fredholm, 2010). Recently ATP receptors have also been identified in plants which are activated in response to tissue wound (Choi et al., 2014). Called DORN1 (Does not Respond to Nucleotides 1), these receptors, much like their mammalian counterparts, show high affinity to ATP and alter $\mathrm{Ca}^{2+}$ flow.

\section{EXOGENOUS ATP HAS BOTH POSITIVE AND NEGATIVE ROLES IN INFLAMMATION}

The presence of functionally active purinergic receptors on microglia indicates the likelihood of astrocyte-microglia crosstalk (Verderio and Matteoli, 2001). Such a communication enhances microglial surveillance system and their response to inflammation within the CNS. Indeed, neuronal and astrocytic release of ATP during traumatic brain injury causes rapid microglial chemotactic response (Davalos et al., 2005). At the site of injury, exogenous ATP mediates the release of pro-inflammatory cytokines and $\mathrm{PGE}_{2}$ (Xu et al., 2003; Ferrari et al., 2006; Xia and Zhu, 2011). The end effect of this synergism is the production of pathological levels of inflammatory cytokines and prostanoids.

While the above reports suggest extracellular ATP as proinflammatory, others have reported to the contrary. In LPS-primed cells, ATP inhibited the release of cytokines from spinal cord microglia (Ogata et al., 2003), nitric oxide (NO) release in BV-2 microglia (Brautigam et al., 2005), and pro-inflammatory markers such as tumor necrosis factor $\alpha$ (TNF- $\alpha$ ), interleukin 6 (IL6 ) and NO in primary microglia (Boucsein et al., 2003). Since TNF- $\alpha$ and IL-6 also have neuroprotective roles (Suzuki et al., 2004; Noguchi et al., 2013), the above inhibitory action of ATP may actually be detrimental to the organism. Increases in exogenous ATP need not always be hazardous-extracellular levels of adenosine increases 6- to 31-fold within the hippocampus of patients with epilepsy, but acts as a natural anticonvulsant terminating seizure (During and Spencer, 1992). Interestingly, cancer cells evade surveillance by up-regulating a subpopulation of regulatory T cells expressing ectonucleotidases CD39 and CD73 to exploit the immunosuppressive nature of adenosine (Whiteside and Jackson, 2013). Early development of nervous system is dependent on purinergic signals, which in concert with growth factors, regulate the number of proliferating and differentiating neural stem cells (Ulrich et al., 2012).

\section{P2 RECEPTORS DETERMINE THE EVENTUAL EFFECT OF EXTRACELLULAR ATP ${\mathrm{P} 2 \mathrm{X}_{7} \text { RECEPTORS }}$}

The specific roles of $\mathrm{P} 2$ receptors in neuroinflammation are still being uncovered. The subject is still in its teens, starting with the discovery of ATP enhancing IL- $1 \beta$ release in activated immune cells (Ferrari et al., 1997). LPS-mediated activation of toll-like receptor 4 leads to the formation of the inflammasome complex wherein IL- $1 \beta$ processing occurs (Martinon et al., 2002). However, release of IL-1 $\beta$ requires loading of the inflammasome complex into the secretory lysosome, or the formation of membrane blebs-either mechanism triggered through $\mathrm{P}_{2} \mathrm{X}_{7}$ receptor-mediated $\mathrm{K}^{+}$efflux (Ferrari et al., 2006; di Virgilio, 2007). As a result, the effect of ATP is dependent on cells primed with LPS, and conversely, LPS does not release IL-1 $\beta$ in the absence of $\mathrm{P}_{2} \mathrm{X}_{7}$ receptors (Solle et al., 2001). Pannexin 1, a gap junction-related protein, has been shown to be responsible for the release of ATP from dying cells, leading to the activation of the inflammasome and recruitment of phagocytes (Dahl and Keane, 2012). Intraperitoneal injection of LPS results in two-fourfold higher detection of ATP in the mouse peritoneum (BarberàCremades et al., 2012). Systemic administration of LPS markedly increases the expression of $\mathrm{P}_{2} \mathrm{X}_{7}$ receptors in the brain (Choi et al., 2007). LPS- or IL-1 $\beta$-mediated febrile response is greatly reduced in mice with genetic or pharmacological loss of $\mathrm{P}_{2} \mathrm{X}_{7}$ receptors (Barberà-Cremades et al., 2012). ATP and the preferential P2X 7 agonist, 2'(3')-O-(4-benzoylbenzoyl) ATP (BzATP) induce the secretion of cytokines IL- 6 and TNF- $\alpha$ in wildtype microglia but not in cells derived from $\mathrm{P}_{2} \mathrm{X}_{7}{ }^{-/-}$mice (Shieh et al., 2014). These reports underline the importance of $\mathrm{P}_{2} \mathrm{X}_{7}$ receptors in mediating inflammation, especially in the release of IL-1 $\beta$ (Ferrari et al., 2006). The low affinity of $\mathrm{P}_{2} \mathrm{X}_{7}$ receptors for extracellular ATP ensures their activation occurs only under pathological conditions where excess ATP is found, further supporting the notion of exogenous ATP as an "alarm" signal.

Immunohistochemical analysis of $\mathrm{AD}$ brains reveal significant levels of $\mathrm{P}_{2} \mathrm{X}_{7}$ receptors colocalized with activated microglia, an observation that was also found in the hippocampus of rats injected with $\mathrm{A} \beta_{1-42}$ (McLarnon et al., 2006). A $\beta$ triggers ATP release, membrane permeabilization and IL- $1 \beta$ secretion in wildtype but not in $\mathrm{P}_{2} \mathrm{X}_{7}^{-/-}$mouse (Sanz et al., 2009). In fact, overexpression of $\mathrm{P}_{2} \mathrm{X}_{7}$ receptor itself, in the absence of any proinflammatory stimuli, can drive the activation and proliferation of microglial cells (Monif et al., 2009). Similarly, exposure to high levels of extracellular ATP can also tilt the signaling mechanism from a P2X7-phosphatidylinositol 3-kinase/Akt-mediated growth pathway to a novel P2X7-AMPK-mammalian target of rapamycin (mTOR)-mediated autophagic pathway, as observed in tumor cells (Bian et al., 2013). Rapamycin reduces neuroinflammation and brain lesions in a mouse model of Leigh syndrome (Johnson et al., 2013). In astrocytes, inhibition of mTOR significantly reduces the stability of inducible nitric oxide synthase (iNOS) mRNA (Lisi et al., 2011). However, in microglia, blocking of mTOR pathway in activated cells leads to enhanced $\mathrm{PGE}_{2}$ synthesis (de Oliveira et al., 2012). Activated microglia downregulate microRNA, miRNA-200b, which leads to increased c-Jun Nterminal kinase (JNK) activity leading to increased iNOS expression (Jadhav et al., 2014). These observations suggest that the role of mTOR in neuroinflammation is cell-type specific and depends on both epigenetic factors and the presence of inflammatory stimuli.

Gene expression studies in $A \beta$-treated microglia derived from human post-mortem brains, in fact, suggest that the expression of pro-inflammatory genes are largely up-regulated at the expense of genes involved in $\mathrm{A} \beta$ phagocytosis and removal (Walker et al., 2006). Activated $\mathrm{P} 2 \mathrm{X}_{7}$ receptors impair lysosomal function and instead stimulate the release of autolysosomal contents into the 
extracellular space, possibly leading to the increased secretion of IL-1 $\beta$ or amyloidogenic proteins (Takenouchi et al., 2009). In corollary, silencing of $\mathrm{P}_{2} \mathrm{X}_{7}$ receptors in $\mathrm{A} \beta$-stimulated cells leads to a decreased release of pro-inflammatory cytokines and a marked increase in the phagocytosis of $\mathrm{A} \beta_{1-42}$ peptide (Ni et al., 2013). $\mathrm{P}_{2} \mathrm{X}_{7}$ receptors, therefore, turn phagocytic (neuroprotective) microglia into inflammatory (neurodegenerative) phenotype.

Expression of $\mathrm{P}_{2} \mathrm{X}_{7}$ receptors is also up-regulated in Huntington's disease and amyotrophic lateral sclerosis (ALS; DíazHernández et al., 2009). In microglia isolated from superoxide dismutase SOD1-G93A mutant mouse model of ALS, activation of $\mathrm{P}_{2} \mathrm{X}_{7}$ receptors enhances oxidative stress (Apolloni et al., 2013). Oxidative stress drives the nitration of $90 \mathrm{kDa}$ heatshock protein (Hsp90), which mediates cell death through $\mathrm{P}_{2} \mathrm{X}_{7}$ receptors (Franco et al., 2013). Nitrated Hsp90 is found in the motor neurons of patients with ALS; and as expected, deletion of $\mathrm{P}_{2} \mathrm{X}_{7}$ receptors prevents the neurotoxic effects of nitrated Hsp90.

Imbalances in energy homeostasis are associated with neurodegenerative disorders (Akundi et al., 2013). Over-activation of poly (ADP-ribose) polymerase 1 (PARP1) contribute towards dopaminergic degeneration in Parkinson's disease (PD), which is completely absent in PARP1 $1^{-/-}$mice (Kim et al., 2013). PARP1 activation leads to depletion of cytosolic NAD ${ }^{+}$. Replenishment of $\mathrm{NAD}^{+}$prevents PARP1-mediated neuronal death (Alano et al., 2010). Exogenous $\mathrm{NAD}^{+}$, surprisingly, enters neurons through the dilated $\mathrm{P}_{2} \mathrm{X}_{7}$ receptor-gated channels, marking a neuroprotective role for the otherwise proinflammatory $\mathrm{P} 2 \mathrm{X}_{7}$ receptors.

Among other neuroprotective roles, various in vitro models show that activation of $\mathrm{P} 2 \mathrm{X}_{7}$ receptors stimulates $\alpha$-secretase activity leading to the shedding of non-amyloidogenic soluble amyloid precursor protein (APP; Darmellah et al., 2012). On the contrary, inhibition of $\mathrm{P}_{2} \mathrm{X}_{7}$ receptors in a transgenic mouse for mutant human APP show a significant decrease in the number of amyloid plaques through increased activity of $\alpha$-secretase (Diaz-Hernandez et al., 2012). Such opposing roles could be best explained with the discovery of a shorter, natural, splice variant of $\mathrm{P}_{2} \mathrm{X}_{7}$ receptor that exhibits neurotrophic properties (Adinolfi et al., 2010). Though it remains to be investigated, it is probable that the truncated $\mathrm{P} 2 \mathrm{X}_{7}$ receptors induce $\alpha$-secretase activity while the longer isoforms are inhibitory. The factors that mediate the retention or deletion of the C-terminal part of $\mathrm{P}_{2} \mathrm{X}_{7}$ receptors are not yet known. Such contrasting roles of $\mathrm{P} 2 \mathrm{X}_{7}$ receptors have also been identified in other cellular systems such as cancer (Feng et al., 2006). The distribution of short and long isoforms of $\mathrm{P}_{2} \mathrm{X}_{7}$ within the receptor heterotrimer most likely determines its overall trophic or toxic nature.

\section{P2X 4 RECEPTORS}

An interesting use of neuronal P2 receptors as "flags" for microglial recognition has been reported. In the mutant superoxide dismutase SOD1 mouse model of ALS, degenerating motor neurons typically express $\mathrm{P} 2 \mathrm{X}_{4}$ receptors for the recruitment and eventual engulfment by activated microglia (Casanovas et al., 2008). Unlike a typical cell undergoing apoptosis, $\mathrm{P}_{2} \mathrm{X}_{4}$-positive neurons neither show chromatin condensation nor caspase 3 activity; rather exhibit loss of neuronal NeuN marker and recruitment of microglial cells. It is not just restricted to motor neurons but to other degenerating neurons affected with ALSserotonergic neurons of raphe nucleus, noradrenergic neurons of locus coeruleus, and Purkinje cells in the cerebellum. In $\mathrm{A} \beta_{1-42-}$ treated neurons that do undergo caspase 3-mediated apoptosis, increased surface expression of $\mathrm{P}_{2} \mathrm{X}_{4}$ receptors occurs due to the unique presence of a putative caspase 3 cleavage site within the $\mathrm{C}$ terminus region (Varma et al., 2009). Hence, overexpression of $\mathrm{P}_{2} \mathrm{X}_{4}$ receptors enhances $\mathrm{A} \beta$-induced neuronal death, while receptor inhibition subdues cell death. These reports form the basis for our hypothesis that surface expression of $\mathrm{P} 2 \mathrm{X}_{4}$ receptors may serve as markers for degenerating neurons, attracting microglial cells for eventual engulfment.

On the other hand microglial $\mathrm{P}_{2} \mathrm{X}_{4}$ receptor expression is associated with increased neurophagic activity (Cavaliere et al., 2003). Knocking out $\mathrm{P}_{2} \mathrm{X}_{4}$ receptors results in poorer microglial activation and loss of $\mathrm{PGE}_{2}$-mediated inflammatory pathway (Ulmann et al., 2010). $\mathrm{P}_{2} \mathrm{X}_{4}$ receptor forms a large conductance pore on the cell surface affecting ionic balance, thus mediating the release of proinflammatory substances. Constitutively, $\mathrm{P}_{2} \mathrm{X}_{4}$ receptors are trafficked into late endosomes and remain resistant to lysosomal degradation (Robinson and MurrellLagnado, 2013). Such a mechanism prevents the "flagging" of healthy neurons or the "activation" of microglia under normal physiology.

\section{OTHER P2X RECEPTORS}

Slow neurodegeneration, following axotomy, shows an upregulation of $\mathrm{P} 2 \mathrm{X}_{1}$ and $\mathrm{P} 2 \mathrm{X}_{2}$ receptors, synchronous with upregulation of neuronal nitric oxide synthase (nNOS; Viscomi et al., 2004). $\mathrm{P} 2 \mathrm{X}$ receptors further mediate translocation of $\mathrm{nNOS}$ to the plasma membrane (Ohnishi et al., 2009). In an animal model of $\mathrm{PD}$, dopamine denervation upregulates $\mathrm{P}_{2} \mathrm{X}_{1}, \mathrm{P} 2 \mathrm{X}_{3}, \mathrm{P} 2 \mathrm{X}_{4}$ and $\mathrm{P} 2 \mathrm{X}_{6}$ receptors on nigral GABAergic neurons to compensate the loss of dopamine (Amadio et al., 2007). Coincidentally, within the substantia nigra, two out of five groups of GABAergic neurons, but none of the five groups of dopaminergic neurons, express nNOS (González-Hernández and Rodríguez, 2000). Whether P2X and nNOS are upregulated within the same cell during neurodegeneration is not known; however, coordinated activation of purinergic and nitrergic mediators seems a likely event during neuroinflammation.

\section{P2Y RECEPTORS}

The metabotropic P2Y receptors play a major role in neuronglia communication. Neuronal injuries activate astrocytic $\mathrm{P}_{2} \mathrm{Y}_{1}$ receptors leading to the release of $\mathrm{PGE}_{2}$, causing reactive gliosis (Xia and Zhu, 2011), or glutamate, mediating synaptic modulation (Domercq et al., 2006). Blocking of $\mathrm{P}_{2} \mathrm{Y}_{1}$ receptors therefore reduces glial activity (Davalos et al., 2005) and improves cognitive outcome following traumatic brain injury (Choo et al., 2013). In the $\mathrm{AD}$ brain, $\mathrm{P}_{2} \mathrm{Y}_{1}$ receptors are localized in the neurofibrillary tangles and neuritic plaques (Moore et al., 2000). In contrast, there is a selective loss of $\mathrm{P}_{2} \mathrm{Y}_{2}$ receptors correlating with worsening neuropathological scores (Lai et al., 2008). 
This is not surprising since $\mathrm{P}_{2} \mathrm{Y}_{2}$ receptors stimulate $\alpha$-secretase activity (Camden et al., 2005). In addition, $\mathrm{P} 2 \mathrm{Y}_{2}$ receptors mediate microglial phagocytosis of fibrillar forms of $A \beta$ in a mouse model of $\mathrm{AD}$ (Ajit et al., 2014). The soluble $\mathrm{A} \beta$ peptides are instead cleared through ATP-dependent $\mathrm{P}_{2} \mathrm{Y}_{4}$ receptor-mediated pinocytosis ( $\mathrm{Li}$ et al., 2013). In fact soluble $A \beta_{1-42}$ itself induces ATP release, auto-stimulating $\mathrm{P}_{2} \mathrm{Y}_{4}$ receptors in microglia, thus mediating its own clearance. Degradation of extracellular amyloid peptides is also performed by metallopeptidases such as matrix metalloproteinase 9 (MMP-9), whose secretion is upregulated following inhibition of the tonically active $\mathrm{P}_{2} \mathrm{Y}_{14}$ receptors (Kinoshita et al., 2013). These reports suggest that the loss of $\mathrm{P}_{2} \mathrm{Y}_{2}$ and $\mathrm{P}_{2} \mathrm{Y}_{4}$ receptors or an overactivation of $\mathrm{P} 2 \mathrm{Y}_{1}$ and $\mathrm{P} 2 \mathrm{Y}_{14}$ receptors alter the steady state levels of amyloid peptides leading to $\mathrm{AD}$.

Both $\mathrm{P}_{2} \mathrm{Y}_{2}$ and $\mathrm{P}_{2} \mathrm{Y}_{4}$ receptors are preferentially expressed in perivascular astrocytes, and in response to exogenous ATP, mediate increased levels of cytosolic calcium within their endfeet processes (da Silva et al., 2009). As a result, P2Y receptors influence the permeability of blood-brain barrier through induction of endothelial nitric oxide synthase (eNOS). Activated glial cells also induce the expression of chemokines such as monocyte chemotactic protein 1 (MCP1) leading to the CNS recruitment of monocytes (Kim et al., 2011). Interestingly, MCP1 deficiency decreases microglial phagocytosis of $A \beta$ oligomers, thus contributing to progressive amyloidosis (Kiyota et al., 2013).

$\mathrm{UDP}$ is the ligand of choice for $\mathrm{P}_{2} \mathrm{Y}_{6}$ receptors. Activated $\mathrm{P}_{2} \mathrm{Y}_{6}$ receptors trigger a change in microglial phenotypefrom active motile/surveillance cells to active neuron devouring/phagocytic cells (Koizumi et al., 2007). The neurophagic activity of microglial cells is potentiated by TNF- $\alpha$, LPS or A $\beta$ peptides, and delayed through $\mathrm{P}_{2} \mathrm{Y}_{6}$ receptor antagonists (Neher et al., 2014). Furthermore, activated $\mathrm{P}_{2} \mathrm{Y}_{6}$ receptors block dilation of $\mathrm{P}_{2} \mathrm{X}_{4}$ receptor-mediated channels, shifting microglial phenotype from inflammatory to phagocytic cells (Bernier et al., 2013). Blocking of $\mathrm{P}_{2} \mathrm{Y}_{6}$ receptors increases neuronal survival suggesting that phagocytosis is not limited to degenerating neurons alone but non-specifically targets "stressed-but-otherwise-viable" neurons as well (Emmrich et al., 2013). Irrespective of the type of insult, the release of UDP signals microglia to initiate indiscriminate phagocytosis found in neurodegenerative disorders.

The migration of microglial cells to the site of injury is mediated by $\mathrm{P}_{2} \mathrm{Y}_{12}$ receptors (Haynes et al., 2006). In mice lacking $\mathrm{P}_{2} \mathrm{Y}_{12}$ receptors, microglia fail to polarize and migrate towards the lesion site while overactivation of $\mathrm{P}_{2} \mathrm{Y}_{12}$ receptors enhances neuroinflammation. As a result $\mathrm{P} 2 \mathrm{Y}_{12}{ }^{+/-}$mice show lesser severity of neuronal injury following cerebral ischemia compared to P2 $\mathrm{Y}_{12}{ }^{+/+}$littermates (Webster et al., 2013). Interestingly, loss of the transcriptional factor interferon regulatory factor 8 (IRF8) suppresses microglial chemotaxis (Masuda et al., 2014). Irf8-/microglia show reduced expression of $\mathrm{P}_{2} \mathrm{Y}_{12}, \mathrm{P}_{2} \mathrm{X}_{4}$ and adenosine $\mathrm{A}_{3}$ receptors - all involved in microglial activation and migration to the site of injury. As a result, $\operatorname{Irf} 8^{-/-}$mice are resistant to experimental autoimmune encephalitis (EAE) — a mouse model of multiple sclerosis (Yoshida et al., 2014).

ADP, formed by the activity of ectonucleotidases on extracellular ATP, is the preferred ligand for $\mathrm{P}_{2} \mathrm{Y}_{13}$ receptors. Ubiquitination at its C-terminal end leads to proteasomal degradation and poor surface expression (Pons et al., 2014). However its surface expression increases in response to oxidative stress and genotoxins such as cisplatin or UV irradiation (Morente et al., 2014). In the red blood cells, $\mathrm{ADP}$-activated $\mathrm{P}_{2} \mathrm{Y}_{13}$ receptors show a negative feedback loop by inhibiting ATP release (Wang et al., 2005). Such a mechanism ensures additional regulation of extracellular ATP during neuronal injuries by restricting the lesion area such that undamaged and far away neurons which are exposed to ADP are not activated.

\section{ADENOSINE RECEPTORS}

Enhanced neuroinflammation and microglial activity is a feature of $A_{1}$ adenosine receptor knockout mice $\left(A_{1} A R^{-/}\right)$, suggesting that activation of $A_{1} A R s$ is neuroprotective under pathological conditions (Luongo et al., 2014). On the other hand, $A_{2 A}$ receptors facilitate glutamate release, and their association with ectonucleotidase, $\mathrm{CD} 73$, implies $\mathrm{A}_{2 \mathrm{~A}}$ receptors are activated under pathological conditions when excess extracellular ATP is found (Augusto et al., 2013). Hence $\mathrm{A}_{2 \mathrm{~A}}$ receptor antagonists such as caffeine limit the pathology of neurodegenerative disorders such as $\mathrm{AD}$ and $\mathrm{PD}$. Interestingly, in mouse models of senescence, $\mathrm{A}_{1} \mathrm{ARs}$ significantly decrease with age while $\mathrm{A}_{2 \mathrm{~A}}$ receptors increase with age (Castillo et al., 2009). A higher density of $A_{2 A}$ receptors in the putamen of PD patients also correlates with increasing motor symptoms (Varani et al., 2010). A 2 A receptors induce microglial COX-2 expression (Fiebich et al., 1996) and inhibit astrocyte glutamate uptake by interacting with the $\alpha 2$ subunits of $\mathrm{Na}^{+} / \mathrm{K}^{+}$-ATPase (Matos et al., 2013). Though activation of $\mathrm{A}_{1} \mathrm{ARs}$ and inhibition of $\mathrm{A}_{2 \mathrm{~A}}$ receptors provide neuroprotection in the adult brain, the opposite is true for the embryonic brain. Chronic hypoxia mediates accelerated maturation of oligodendrocyte progenitor cells leading to hypomyelination and ventriculomegaly in mice (Akundi and Rivkees, 2009). Deletion of $A_{1}$ ARs or early intervention with caffeine rescues embryos against hypoxia-mediated white matter injury (Back et al., 2006). Similarly, hypoxic ischemia-mediated brain damage was more profound in newborn $\mathrm{A}_{2 \mathrm{~A}}{ }^{-/-}$mice compared with their wildtype littermates (Adén et al., 2003). Similarly, it has been observed that $\mathrm{A}_{2 \mathrm{~A}}$ receptor agonists show synergy with agonists of certain toll-like receptors, such as TLR2, 4, 7 and 9, in selectively upregulating the expression of vascular endothelial growth factor and downregulating the release of TNF- $\alpha$ (Pinhal-Enfield et al., 2003). Such a synergistic mechanism provides an angiogenic role for macrophages making it relevant in the aftermath of cerebral ischemia.

Adenosine $\mathrm{A}_{3}$ receptors mediate microglial process extension (Ohsawa et al., 2012). Agonists of $A_{3}$ receptors thereby provide neuroprotection against ischemia (Choi et al., 2011). However, during chronic neuroinflammation microglia undergo process retraction through upregulation of adenosine $\mathrm{A}_{2 \mathrm{~A}}$ receptors (Orr et al., 2009). $A_{2 A}$ receptor-dependent process retraction is also seen in the substantia nigra of mice treated with 1-methyl-4phenyl-1,2,3,6-tetrahydropyridine (MPTP) for 5 days (Gyoneva et al., 2014). $A_{2 A}$ receptor-mediated loss of process extension (due to $\mathrm{A}_{3}$ receptors) and chemotaxis (due to $\mathrm{P} 2 \mathrm{Y}_{12}$ receptors) thereby dampens microglial response to injury. Microglial cells 
also express $\alpha 7$ nicotinic acetylcholine receptor. Activation of these receptors attenuates neuroinflammation in a mouse model of MPTP (Liu et al., 2012). Coincidentally, nicotinic acetylcholine receptor stimulation mediates dopamine release in the rat striatum which is negatively regulated by agonists of adenosine $A_{2 A}$ receptors (Garção et al., 2013). These observations suggest that adenosine $\mathrm{A}_{2 \mathrm{~A}}$ receptors regulate various neurotransmitter systems, and use of specific antagonists of $A_{2 A}$ receptors, therefore, show potential as therapeutic alternatives for PD (Threlfell et al., 2012).

\section{TARGETING P2 RECEPTORS MAY BE AN ATTRACTIVE THERAPEUTIC APPROACH OVER COX2 INHIBITION}

Neuroinflammation in AD was promisingly approached through the use of NSAIDs (Szekely and Zandi, 2010). Following failures in clinical trials, the $\mathrm{AD}$ Anti-inflammatory Prevention Trial (ADAPT) group found that neither celecoxib nor naproxen prevented $\mathrm{AD}$ in adults with a family history of dementia (Breitner et al., 2013). The drawback of using COX inhibitors lies in the ubiquitous presence and role of its product, $\mathrm{PGE}_{2}$. $\mathrm{PGE}_{2}$ plays an important role in gastro-intestinal (GI secretion, bowel motility), cardiovascular (regulates blood pressure), renal (hemodynamics in the glomeruli), and reproductive (embryo implantation, uterine contraction) systems; and within the CNS, regulates body temperature, sleep-wake cycle, memory consolidation and synaptic plasticity. The relative contribution of either COX isoforms in mediating the above functions is unclear. Selective COX-2 antagonists were designed to target the excess $\mathrm{PGE}_{2}$ formed during neuroinflammatory episodes with the consideration that the more ubiquitous COX-1 would suffice for the production of physiological levels of $\mathrm{PGE}_{2}$. However, despite better gastrointestinal safety ratio, selective COX-2 inhibitors showed increased risks of myocardial infarction, stroke, systemic and pulmonary hypertension, and sudden cardiac death (Jüni et al., 2004). The multiple deaths led to the eventual withdrawal of COX-2 inhibitors such as rofecoxib leading to sweeping lawsuits and wider criticism of the drug licensing procedures.

In this scenario targeting $\mathrm{P} 2$ receptors, which modulate $\mathrm{PGE}_{2}$ synthesis, comes as a promising therapeutic possibility (Figure 1). The rat COX-2 promoter carries consensus sequences for tran-

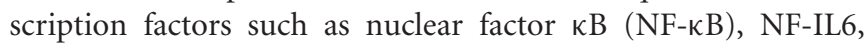
AP-1 and cAMP-responsive element (Tanabe and Tohnai, 2002). In addition, COX-2 can also be epigenetically regulated with hypermethylation responsible for its silencing in various types of cancer (Lodygin et al., 2005; Castells et al., 2006). Epigenetic contribution in the development of multiple sclerosis and neurodegenerative disorders is slowly being recognized, although evidences for such changes on $\mathrm{P} 2$ receptor genes is not yet known (Noh et al., 2012; Koch et al., 2013; Qureshi and Mehler, 2013). Furthermore, COX-2 is posttranscriptionally regulated as well. The human COX-2 mRNA contains at least 23 AU-rich elements (AREs) in the $3^{\prime}$-untranslated region (UTR) conferring to its instability (Shaw and Kamen, 1986). The interactions of ARE-binding protein with the $5^{\prime}$-methylguanosine cap-binding protein and polyadenosine tail-binding protein can either further stabilize the mRNA or lead to its degradation through recruitment of deadenylases (Dean et al., 2004). The p38 mitogen-activated protein kinase plays a critical role in the post-transcriptional regulation of several proinflammatory genes through controlling the phosphorylation status of these binding proteins (Clark et al., 2003). Other proteins that bind to COX-2 ARE and lead to its mRNA stabilization include the heat shock protein hsp70 (Kishor et al., 2013), and the RNA-binding protein HuR which inhibits the destabilization of COX-2 mRNA mediated by microRNA miR-16 (Young et al., 2012). Another regulator is the heterogeneous nuclear riboprotein A1 (hnRNP-A1) whose declining levels have been correlated with the severity of symptoms in various neurodegenerative diseases including AD (Bekenstein and Soreq, 2013). It was recently reported to regulate IL-6 transcription, with overexpression of hnRNP-A1 increasing IL-6 expression and knockdown leading to reduced IL-6 synthesis (Zheng et al., 2013). Post-transcriptional and post-translation regulation of various P2 receptors is not yet known, although the various alternate splicing mechanisms as shown in P2X7 (Adinolfi et al., 2010) and adenosine Al receptor (Ren and Stiles, 1994) suggest their involvement. Transcription factors downstream of $\mathrm{P} 2$ receptor activation bind to most of the COX-2 promoter consensus sequences (Brautigam et al., 2005; Ferrari et al., 2006; Lenertz et al., 2011). P2X 7 receptor antagonists present themselves as appropriate therapeutic alternatives to specific COX-2 inhibitors based on several evidences implicating them in neuroinflammation. Currently a few $\mathrm{P} 2$ receptor antagonists have advanced to clinical trials (Arulkumaran et al., 2011; North and Jarvis, 2013). It sets the stage for the potential role of P2 receptor-based anti-inflammatory drugs (PBAIDs) in targeting neuroinflammation.

A considerable roadblock in the design of PBAIDs is inherent in the diversity of $\mathrm{P} 2$ receptors. The conflicting reports on the neuroprotective and pro-inflammatory roles of various P2 receptors stems from the limited understanding of the actual types of receptors expressed, which may differ between cell types, species, age, and physiological status (Crain et al., 2009; Serrano et al., 2012). Nerve injury indiscriminately releases nucleotides of all kinds, including functionally opposing ones. The predominant ligand concentration depends on the distribution and activity of ectonucleotidases. Most studies utilize pharmacological agents which exhibit receptor promiscuity and have been characterized on purified homomers. However, not only surface P2 receptor density changes under pathological conditions, there is also the possibility of formation of heteromultimers (such as $\mathrm{P}_{2} \mathrm{X}_{2 / 6}$, or $\mathrm{P}_{2} \mathrm{X}_{4 / 6}$, and even $\mathrm{P}_{2} \mathrm{X}_{2 / 4 / 6}$ ) with altered ligand affinity and functions (Robinson and Murrell-Lagnado, 2013). The long and short splice variants of $\mathrm{P}_{2} \mathrm{X}_{7}$ receptor have opposing roles on cell growth and death (Adinolfi et al., 2010). Finally, an ideal PBAID has to overcome potential possibilities of receptor compensation. This was particularly evident in the failure of neuroprotection in $\mathrm{P}_{2} \mathrm{X}_{7}{ }^{-/-}$mice where higher numbers of functionally compensating $\mathrm{P}_{2} \mathrm{X}_{4}$ receptors were found instead (Hracskó et al., 2011). In another example, $\mathrm{P} 2 \mathrm{Y}_{12}{ }^{-/-}$mice show delayed microglial response to injury; however, other signaling mechanisms did ensure that microglia reached the site of injury despite the delay (Haynes et al., 2006). The $\mathrm{P}_{2} \mathrm{X}_{2}-\mathrm{P} 2 \mathrm{X}_{5}$ heterotrimer is functionally analogous to $\mathrm{P} 2 \mathrm{X}_{7}$ receptors, including pore dilation, membrane 
blebbing and phosphatidylserine exposure (Compan et al., 2012). Such rich receptor diversity allows $\mathrm{P} 2 \mathrm{X}$ receptors to functionally compensate the loss of other family members. Therefore, more studies are required to correctly identify the aggravating P2 receptor contributing to neuroinflammation. Because of the functional diversity of P2 receptors, PBAIDs should be carefully chosen to target the disease at the appropriate stage where benefit outweighs risk.

\section{SUMMARY}

Conventionally COX-2 has been a target in various inflammatory disorders. However, the failure of NSAIDs and selective enzyme inhibitors reveal the importance of COX-2 not only in various physiological activities but also in tissue repair following neuronal injury. The COX enzymes maintain a delicate balance of tissue scavenging and tissue repair during neuroinflammation. An imbalance could lead to excessive $\mathrm{PGE}_{2}$ activity leading to increased tissue damage or chronic inflammation. All cells within the vertebrate system upon damage (hit one) release large amounts of ATP (hit two) into the extracellular space. The effect of released ATP depends on the nature of two downstream factors-(1) the type of receptors present on cells within the vicinity of the injury; and (2) the distribution and activity of hydrolyzing ectonucleotidases. In large quantities, ATP potentiates the inflammatory reaction while other nucleotides have various modulatory roles in shaping the outcome of inflammation (summarized in Figure 2). PBAIDs aim to reduce the effect of second hit by targeting P2 receptors responsible for

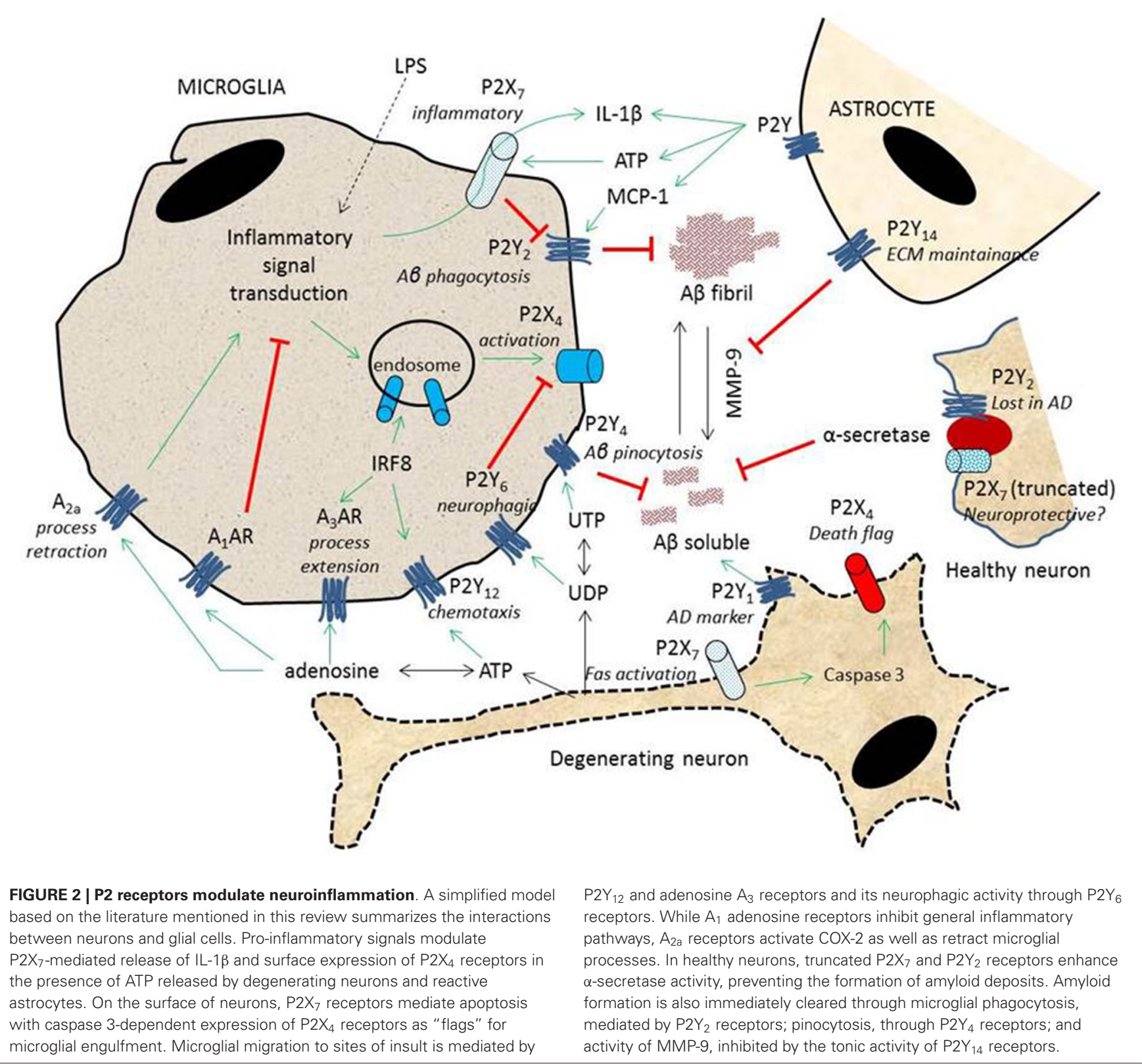


inflammation-enhancement rather than the COX enzymes mediating $\mathrm{PGE}_{2}$ synthesis. By not interfering with the COX system PBAIDs, unlike NSAIDs, retain the housekeeping functions of $\mathrm{PGE}_{2}$, but vastly reduce the pathology through P2 receptor inhibition. Identifying the target $\mathrm{P} 2$ receptor, and designing a selective PBAID, remains a challenge for future therapeutic successes in neuroinflammation. Surface expression of $\mathrm{P} 2$ receptors under certain pathological conditions may depend on epigenetic stimuli. Silenced P2 receptors which were once active during neural development could be reprogrammed in the event of tissue injury. A global study of $\mathrm{P} 2$ receptor density and mutations that affect their binding to specific nucleotides, may identify newer insights into the susceptibility of neurodegenerative disorders to specific populations. Furthermore, it is essential to understand the activity of various ectonucleotidases since the steady-state levels of various nucleotides have contrasting outcome in neuroinflammation. Therapeutically increasing the activity of specific ectonucleotidases following excessive ATP release is another approach to counter neuroinflammation. Finally, the two-hit hypothesis can also be extended to various other inflammatory disorders such as arthritis, toxin exposures including nerve gas poisoning, in the inflammatory model of cancer, and in psychological stress and depression. More studies in these areas will provide new roles for PBAIDs as effective anti-inflammatory drugs.

\section{REFERENCES}

Abbracchio, M. P., Burnstock, G., Verkhratsky, A., and Zimmermann, H. (2009). Purinergic signalling in the nervous system: an overview. Trends Neurosci. 32, 19-29. doi: 10.1016/j.tins.2008.10.001

Adén, U., Halldner, L., Lagercrantz, I., Dalmau, I., Ledent, C., and Fredholm, B. B. (2003). Aggravated brain damage after hypoxic ischemia in immature adenosine A2A knockout mice. Stroke 34, 739-744. doi: 10.1161/01.str.0000060204. $67672.8 \mathrm{~b}$

Adinolfi, E., Cirillo, M., Woltersdorf, R., Falzoni, S., Chiozzi, P., Pellegatti, P., et al. (2010). Trophic activity of a naturally occurring truncated isoform of the P2X7 receptor. FASEB J. 24, 3393-3404. doi: 10.1096/fj.09-153601

Aguzzi, A., Barres, B. A., and Bennett, M. L. (2013). Microglia: scapegoat, saboteur, or something else? Science 339, 156-161. doi: 10.1126/science.1227901

Ajit, D., Woods, L. T., Camden, J. M., Thebeau, C. N., El-Sayed, F. G., Greeson, G. W., et al. (2014). Loss of $\mathrm{P}_{2} \mathrm{Y}_{2}$ nucleotide receptors enhances early pathology in the TgCRND8 mouse model of Alzheimer's disease. Mol. Neurobiol. 49, 10311042. doi: 10.1007/s12035-013-8577-5

Akundi, R. S., Candelario-Jalil, E., Hess, S., Hull, M., Lieb, K., Gebicke-Haerter, P. J., et al. (2005). Signal transduction pathways regulating cyclooxygenase-2 in lipopolysaccharide-activated primary rat microglia. Glia 51, 199-208. doi: 10. 1002/glia.20198

Akundi, R. S., and Rivkees, S. A. (2009). Hypoxia alters cell cycle regulatory protein expression and induces premature maturation of oligodendrocyte precursor cells. PLoS One 4:e4739. doi: 10.1371/journal.pone.0004739

Akundi, R. S., Zhi, L., Sullivan, P. G., and Bueler, H. (2013). Shared and cell typespecific mitochondrial defects and metabolic adaptations in primary cells from Pink1-deficient mice. Neurodegener. Dis. 12, 136-149. doi: 10.1159/000345689

Alano, C. C., Garnier, P., Ying, W., Higashi, Y., Kauppinen, T. M., and Swanson, R. A. (2010). NAD+ depletion is necessary and sufficient for poly(ADP-ribose) polymerase-1-mediated neuronal death. J. Neurosci. 30, 2967-2978. doi: 10. 1523/JNEUROSCI.5552-09.2010

Amadio, S., Montilli, C., Picconi, B., Calabresi, P., and Volonte, C. (2007). Mapping $\mathrm{P} 2 \mathrm{X}$ and $\mathrm{P} 2 \mathrm{Y}$ receptor proteins in striatum and substantia nigra: an immunohistological study. Purinergic Signal. 3, 389-398. doi: 10.1007/s11302-0079069-8

Apolloni, S., Parisi, C., Pesaresi, M. G., Rossi, S., Carri, M. T., Cozzolino, M., et al. (2013). The NADPH oxidase pathway is dysregulated by the P2X7 receptor in the SOD1-G93A microglia model of amyotrophic lateral sclerosis. J. Immunol. 190, 5187-5195. doi: 10.4049/jimmunol.1203262

Arulkumaran, N., Unwin, R. J., and Tam, F. W. (2011). A potential therapeutic role for $\mathrm{P} 2 \mathrm{X} 7$ receptor $(\mathrm{P} 2 \mathrm{X} 7 \mathrm{R})$ antagonists in the treatment of inflammatory diseases. Expert Opin. Investig. Drugs 20, 897-915. doi: 10.1517/13543784.2011. 578068

Augusto, E., Matos, M., Sevigny, J., El-Tayeb, A., Bynoe, M. S., Muller, C. E., et al. (2013). Ecto-5' -nucleotidase (CD73)-mediated formation of adenosine is critical for the striatal adenosine A2A receptor functions. J. Neurosci. 33, 1139011399. doi: 10.1523/JNEUROSCI.5817-12.2013

Back, S. A., Craig, A., Luo, N. L., Ren, J., Akundi, R. S., Ribeiro, I., et al. (2006). Protective effects of caffeine on chronic hypoxia-induced perinatal white matter injury. Ann. Neurol. 60, 696-705. doi: 10.1002/ana.21008

Barberà-Cremades, M., Baroja-Mazo, A., Gomez, A. I., Machado, F., Di Virgilio, F., and Pelegrín, P. (2012). P2X7 receptor-stimulation causes fever via PGE2 and IL-1 $\beta$ release. FASEB J. 26, 2951-2962. doi: 10.1096/fj.12-205765

Bekenstein, U., and Soreq, H. (2013). Heterogeneous nuclear ribonucleoprotein $\mathrm{A} 1$ in health and neurodegenerative disease: from structural insights to posttranscriptional regulatory roles. Mol. Cell. Neurosci. 56, 436-446. doi: 10.1016/j. mcn.2012.12.002

Bernier, L.-P., Ase, A. R., Boue-Grabot, E., and Seguela, P. (2013). Inhibition of P2X4 function by P2Y6 UDP receptors in microglia. Glia 61, 2038-2049. doi: 10. 1002/glia.22574

Bian, S., Sun, X., Bai, A., Zhang, C., Li, L., Enjyoji, K., et al. (2013). P2X7 integrates PI3K/AKT and AMPK-PRAS40-mTOR signalling pathways to mediate tumour cell death. PLoS One 8:e60184. doi: 10.1371/journal.pone.0060184

Boucsein, C., Zacharias, R., Farber, K., Pavlovic, S., Hanisch, U.-K., and Kettenmann, H. (2003). Purinergic receptors on microglial cells: functional expression in acute brain slices and modulation of microglial activation in vitro. Eur. J. Neurosci. 17, 2267-2276. doi: 10.1046/j.1460-9568.2003.02663.x

Brautigam, V. M., Frasier, C., Nikodemova, M., and Watters, J. J. (2005). Purinergic receptor modulation of BV-2 microglial cell activity: potential involvement of p38 MAP kinase and CREB. J. Neuroimmunol. 166, 113-125. doi: 10.1016/j. jneuroim.2005.05.012

Breitner, J., Baker, L., Drye, L., Evans, D., Lyketsos, C., Ryan, L., et al. (2013). Results of a follow-up study to the randomized Alzheimer's Disease Anti-inflammatory Prevention Trial (ADAPT). Alzheimers Dement. 9, 714-723. doi: 10.1016/j.jalz. 2012.11.012

Camden, J. M., Schrader, A. M., Camden, R. E., Gonzalez, F. A., Erb, L., Seye, C. I., et al. (2005). P2Y2 nucleotide receptors enhance alpha-secretase-dependent amyloid precursor protein processing. J. Biol. Chem. 280, 18696-18702. doi: 10. 1074/jbc.m500219200

Casanovas, A., Hernandez, S., Tarabal, O., Rossello, J., and Esquerda, J. E. (2008). Strong $\mathrm{P}_{2} \mathrm{X}_{4}$ purinergic receptor-like immunoreactivity is selectively associated with degenerating neurons in transgenic rodent models of amyotrophic lateral sclerosis. J. Comp. Neurol. 506, 75-92. doi: 10.1002/cne.21527

Castells, A., Payá, A., Alenda, C., Rodríguez-Moranta, F., Agrelo, R., Andreu, M., et al. (2006). Cyclooxygenase 2 expression in colorectal cancer with DNA mismatch repair deficiency. Clin. Cancer Res. 12, 1686-1692. doi: 10.1158/10780432.ccr-05-1581

Castillo, C. A., Albasanz, J. L., Leon, D., Jordan, J., Pallas, M., Camins, A., et al. (2009). Age-related expression of adenosine receptors in brain from the senescence-accelerated mouse. Exp. Gerontol. 44, 453-461. doi: 10.1016/j.exger. 2009.04.006

Cavaliere, F., Florenzano, F., Amadio, S., Fusco, F. R., Viscomi, M. T., D’Ambrosi, N., et al. (2003). Up-regulation of P2X2, P2X4 receptor and ischemic cell death: prevention by P2 antagonists. Neuroscience 120, 85-98. doi: 10.1016/s03064522(03)00228-8

Choi, I. Y., Lee, J. C., Ju, C., Hwang, S., Cho, G. S., Lee, H. W., et al. (2011). A3 adenosine receptor agonist reduces brain ischemic injury and inhibits inflammatory cell migration in rats. Am. J. Pathol. 179, 2042-2052. doi: 10. 1016/j.ajpath.2011.07.006

Choi, H. B., Ryu, J. K., Kim, S. U., and McLarnon, J. G. (2007). Modulation of the purinergic $\mathrm{P} 2 \mathrm{X}_{7}$ receptor attenuates lipopolysaccharide-mediated microglial activation and neuronal damage in inflamed brain. J. Neurosci. 27, 4957-4968. doi: 10.1523/jneurosci.5417-06.2007

Choi, J., Tanaka, K., Cao, Y., Qi, Y., Qiu, J., Liang, Y., et al. (2014). Identification of a plant receptor for extracellular ATP. Science 343, 290-294. doi: 10.1126/science. 343.6168 .290 
Choo, A. M., Miller, W. J., Chen, Y.-C., Nibley, P., Patel, T. P., Goletiani, C., et al. (2013). Antagonism of purinergic signalling improves recovery from traumatic brain injury. Brain 136, 65-80. doi: 10.1093/brain/aws286

Clark, A. R., Dean, J. L., and Saklatvala, J. (2003). Post-transcriptional regulation of gene expression by mitogen-activated protein kinase p38. FEBS Lett. 546, 37-44. doi: 10.1016/s0014-5793(03)00439-3

Compan, V., Ulmann, L., Stelmashenko, O., Chemin, J., Chaumont, S., and Rassendren, F. (2012). P2X2 and P2X5 subunits define a new heteromeric receptor with P2X7-like properties. J. Neurosci. 32, 4284-4296. doi: 10. 1523/JNEUROSCI.6332-11.2012

Crain, J. M., Nikodemova, M., and Watters, J. J. (2009). Expression of P2 nucleotide receptors varies with age and sex in murine brain microglia. J. Neuroinflammation 6:24. doi: 10.1186/1742-2094-6-24

Dahl, G., and Keane, R. W. (2012). Pannexin: from discovery to bedside in $11 \pm 4$ years? Brain Res. 1487, 150-159. doi: 10.1016/j.brainres.2012.04.058

Darmellah, A., Rayah, A., Auger, R., Cuif, M.-H., Prigent, M., Arpin, M., et al. (2012). Ezrin/radixin/moesin are required for the purinergic P2X7 receptor (P2X7R)-dependent processing of the amyloid precursor protein. J. Biol. Chem. 287, 34583-34595. doi: 10.1074/jbc.M112.400010

da Silva, C. G., Specht, A., Wegiel, B., Ferran, C., and Kaczmarek, E. (2009). Mechanism of purinergic activation of endothelial nitric oxide synthase in endothelial cells. Circulation 119, 871-879. doi: 10.1161/CIRCULATIONAHA. 108.764571

Davalos, D., Grutzendler, J., Yang, G., Kim, J. V., Zuo, Y., Jung, S., et al. (2005). ATP mediates rapid microglial response to local brain injury in vivo. Nat. Neurosci. 8 , 752-758. doi: 10.1038/nn1472

Dean, J. L., Sully, G., Clark, A. R., and Saklatvala, J. (2004). The involvement of AUrich element-binding proteins in p38 mitogen-activated protein kinase pathwaymediated mRNA stabilization. Cell. Signal. 16, 1113-1121. doi: 10.1016/j.cellsig. 2004.04.006

de Oliveira, A. C., Candelario-Jalil, E., Langbein, J., Wendeburg, L., Bhatia, H. S., Schlachetzki, J. C., et al. (2012). Pharmacological inhibition of Akt and downstream pathways modulates the expression of COX-2 and mPGES-1 in activated microglia. J. Neuroinflammation 9:2. doi: 10.1186/1742-2094-9-2

Díaz-Hernández, M., Díez-Zaera, M., Sánchez-Nogueiro, J., Gómez-Villafuertes, R., Canals, J. M., Alberch, J., et al. (2009). Altered P2X7 receptor level and function in mouse models of Huntington's disease and therapeutic efficacy of antagonist administration. FASEB J. 23, 1893-1906. doi: 10.1096/fj.08-122275

Diaz-Hernandez, J. I., Gomez-Villafuertes, R., Leon-Otegui, M., Hontecillas-Prieto, L., Del Puerto, A., Trejo, J. L., et al. (2012). In vivo P2X7 inhibition reduces amyloid plaques in Alzheimer's disease through GSK3 $\beta$ and secretases. Neurobiol. Aging 33, 1816-1828. doi: 10.1016/j.neurobiolaging.2011.09.040

di Virgilio, F. (2007). Liaisons dangereuses: P2X(7) and the inflammasome. Trends Pharmacol. Sci. 28, 465-472. doi: 10.1016/j.tips.2007.07.002

Domercq, M., Brambilla, L., Pilati, E., Marchaland, J., Volterra, A., and Bezzi, P. (2006). P2Y1 receptor-evoked glutamate exocytosis from astrocytes: control by tumour necrosis factor- $\alpha$ and prostaglandins. J. Biol. Chem. 281, 30684-30696. doi: 10.1074/jbc.m606429200

During, M. J., and Spencer, D. D. (1992). Adenosine: a potential mediator of seizure arrest and postictal refractoriness. Ann. Neurol. 32, 618-624. doi: 10.1002/ana. 410320504

Emmrich, J. V., Hornik, T. C., Neher, J. J., and Brown, G. C. (2013). Rotenone induces neuronal death by microglial phagocytosis of neurons. FEBS J. 280, 5030-5038. doi: 10.1111/febs.12401

Feng, Y. H., Li, X., Wang, L., Zhou, L., and Gorodeski, G. I. (2006). A truncated $\mathrm{P} 2 \mathrm{X} 7$ receptor variant $(\mathrm{P} 2 \mathrm{X} 7 \mathrm{j})$ endogenously expressed in cervical cancer cells antagonizes the full-length $\mathrm{P} 2 \mathrm{X} 7$ receptor through hetero-oligomerization. $J$. Biol. Chem. 281, 17228-17237. doi: 10.1074/jbc.m602999200

Ferrari, D., Chiozzi, P., Falzoni, S., Hanau, S., and di Virgilio, F. (1997). Purinergic modulation of IL-1 $\beta$ release from microglial cells stimulated with bacterial endotoxin. J. Exp. Med. 185, 579-582. doi: 10.1084/jem.185.3.579

Ferrari, D., Pizzirani, C., Adinolfi, E., Lemoli, R. M., Curti, A., Idzko, M., et al. (2006). The P2X7 receptor: a key player in IL-1 processing and release. J. Immunol. 176, 3877-3883. doi: 10.4049/jimmunol.176.7.3877

Fiebich, B. L., Biber, K., Lieb, K., van Calker, D., Berger, M., Bauer, J., et al. (1996). Cyclooxygenase-2 expression in rat microglia is induced by adenosine A2a-receptors. Glia 18, 152-160. doi: 10.1002/(sici)10981136(199610) 18:2<152::aid-glia7>3.0.co;2-2
Franco, M. C., Ye, Y., Refakis, C. A., Feldman, J. L., Stokes, A. L., Basso, M., et al. (2013). Nitration of Hsp90 induces cell death. Proc. Natl. Acad. Sci. U S A 110, E1102-E1111. doi: 10.1073/pnas.1215177110

Fredholm, B. B. (2010). Adenosine receptors as drug targets. Exp. Cell Res. 316, 1284-1288. doi: 10.1016/j.yexcr.2010.02.004

Garção, P., Szabó, E. C., Wopereis, S., Castro, A. A., Tomé, A. R., Prediger, R. D., et al. (2013). Functional interaction between presynaptic $\alpha 6 \beta 2$-containing nicotinic and adenosine A2A receptors in the control of dopamine release in the rat striatum. Br. J. Pharmacol. 169, 1600-1611. doi: 10.1111/bph.12234

González-Hernández, T., and Rodríguez, M. (2000). Compartmental organization and chemical profile of dopaminergic and GABAergic neurons in the substantia nigra of the rat. J. Comp. Neurol. 421, 107-135. doi: 10.1002/(sici)10969861(20000522)421:1<107::aid-cne7>3.3.co;2-6

Gourine, A. V., Dale, N., Llaudet, E., Poputnikov, D. M., Spyer, K. M., and Gourine, V. N. (2007). Release of ATP in the central nervous system during systemic inflammation: real-time measurement in the hypothalamus of conscious rabbits. J. Physiol. 585, 305-316. doi: 10.1113/jphysiol.2007.143933

Gyoneva, S., Shapiro, L., Lazo, C., Garnier-Amblard, E., Smith, Y., Miller, G. W., et al. (2014). Adenosine A2A receptor antagonism reverses inflammationinduced impairment of microglial process extension in a model of Parkinson's disease. Neurobiol. Dis. 67, 191-202. doi: 10.1016/j.nbd.2014.03.004

Haynes, S. E., Hollopeter, G. E., Yang, G., Kurpius, D., Dailey, M. E., Gan, W. B., et al. (2006). The P2Y12 receptor regulates microglial activation by extracellular nucleotides. Nat. Neurosci. 9, 1512-1519. doi: 10.1038/nn1805

Hracskó, Z., Baranyi, M., Csölle, C., Gölöncsér, F., Madarász, E., Kittel, A., et al. (2011). Lack of neuroprotection in the absence of P2X7 receptors in toxininduced animal models of Parkinson's disease. Mol. Neurodegener. 6:28. doi: 10 . 1186/1750-1326-6-28

Jadhav, S. P., Kamath, S. P., Choolani, M., Lu, J., and Dheen, S. T. (2014) MicroRNA-200b modulates microglia-mediated neuroinflammation via the cJun/MAPK pathway. J. Neurochem. 130, 388-401. doi: 10.1111/jnc.12731

Johnson, S. C., Yanos, M. E., Kayser, E. B., Quintana, A., Sangesland, M., Castanza, A., et al. (2013). mTOR inhibition alleviates mitochondrial disease in a mouse model of Leigh syndrome. Science 342, 1524-1528. doi: 10.1126/science. 1244360

Jüni, P., Nartey, L., Reichenbach, S., Sterchi, R., Dieppe, P. A., and Egger, M. (2004). Risk of cardiovascular events and rofecoxib: cumulative meta-analysis. Lancet 364, 2021-2029. doi: 10.1016/s0140-6736(04)17514-4

Kim, T. W., Cho, H. M., Choi, S. Y., Suguira, Y., Hayasaka, T., Setou, M., et al. (2013). (ADP-ribose) polymerase 1 and AMP-activated protein kinase mediate progressive dopaminergic neuronal degeneration in a mouse model of Parkinson's disease. Cell Death Dis. 4:e919. doi: 10.1038/cddis.2013.447

Kim, B., Jeong, H. K., Kim, J. H., Lee, S. Y., Jou, I., and Joe, E. H. (2011). Uridine $5^{\prime}$-diphosphate induces chemokine expression in microglia and astrocytes through activation of the P2Y6 receptor. J. Immunol. 186, 3701-3709. doi: 10. 4049/jimmunol.1000212

Kinoshita, M., Nasu-Tada, K., Fujishita, K., Sato, K., and Koizumi, S. (2013). Secretion of matrix metalloproteinase- 9 from astrocytes by inhibition of tonic P2Y14 receptor-mediated signal(s). Cell. Mol. Neurobiol. 33, 47-58. doi: 10. 1007/s10571-012-9869-4

Kishor, A., Tandukar, B., Ly, Y. V., Toth, E. A., Suarez, Y., Brewer, G., et al. (2013). Hsp70 is a novel posttranscriptional regulator of gene expression that binds and stabilizes selected mRNAs containing AU-rich elements. Mol. Cell. Biol. 33, 7184. doi: 10.1128/MCB.01275-12

Kiyota, T., Gendelman, H. E., Weir, R. A., Higgins, E. E., Zhang, G., and Jain, M. (2013). CCL2 affects $\beta$-amyloidosis and progressive neurocognitive dysfunction in a mouse model of Alzheimer's disease. Neurobiol. Aging 34, 1060-1068. doi: 10.1016/j.neurobiolaging.2012.08.009

Koch, M. W., Metz, L. M., and Kovalchuk, O. (2013). Epigenetic changes in patients with multiple sclerosis. Nat. Rev. Neurol. 9, 35-43. doi: 10.1038/nrneurol.2012. 226

Koizumi, S., Shigemoto-Mogami, Y., Nasu-Tada, K., Shinozaki, Y., Ohsawa, K., Tsuda, M., et al. (2007). UDP acting at P2Y6 receptors is a mediator of microglial phagocytosis. Nature 446, 1091-1095. doi: 10.1038/nature05704

Lai, M. K., Tan, M. G., Kirvell, S., Hobbs, C., Lee, J., Esiri, M. M., et al. (2008). Selective loss of P2Y2 nucleotide receptor immunoreactivity is associated with Alzheimer disease neuropathology. J. Neural Transm. 115, 1165-1172. doi: 10. 1007/s00702-008-0067-y 
Lazarowski, E. R., Boucher, R. C., and Harden, T. K. (2003). Mechanisms of release of nucleotides and integration of their action as P2X- and P2Y-receptor activating molecules. Mol. Pharmacol. 64, 785-795. doi: 10.1124/mol.64. 4.785

Lenertz, L. Y., Gavala, M. L., Zhu, Y., and Bertics, P. J. (2011). Transcriptional control mechanisms associated with the nucleotide receptor P2X7, a critical regulator of immunologic, osteogenic and neurologic functions. Immunol. Res. 50, 22-38. doi: 10.1007/s12026-011-8203-4

Li, H.-Q., Chen, C., Dou, Y., Wu, H.-J., Liu, Y.-J., Lou, H.-F., et al. (2013). P2Y 4 receptor-mediated pinocytosis contributes to amyloid beta-induced self-uptake by microglia. Mol. Cell. Biol. 33, 4282-4293. doi: 10.1128/MCB.00544-13

Lisi, L., Navarra, P., Feinstein, D. L., and Dello Russo, C. (2011). The mTOR kinase inhibitor rapamycin decreases iNOS mRNA stability in astrocytes. $J$. Neuroinflammation 8:1. doi: 10.1186/1742-2094-8-1

Liu, Y., Hu, J., Wu, J., Zhu, C., Hui, Y., Han, Y., et al. (2012). $\alpha 7$ nicotinic acetylcholine receptor-mediated neuroprotection against dopaminergic neuron loss in an MPTP mouse model via inhibition of astrocyte activation. J. Neuroinflammation 9:98. doi: 10.1186/1742-2094-9-98

Lodygin, D., Epanchintsev, A., Menssen, A., Diebold, J., and Hermeking, H. (2005) Functional epigenomics identifies genes frequently silenced in prostate cancer. Cancer Res. 65, 4218-4227. doi: 10.1158/0008-5472.can-04-4407

Lucas, S.-M., Rothwell, N. J., and Gibson, R. M. (2006). The role of inflammation in CNS injury and disease. Br. J. Pharmacol. 147, S232-S240. doi: 10.1038/sj.bjp. 0706400

Luongo, L., Guida, F., Imperatore, R., Napolitano, F., Gatta, L., Cristino, L., et al. (2014). The Al adenosine receptor as a new player in microglial physiology. Glia 62, 122-132. doi: 10.1002/glia.22592

Martinon, F., Burns, K., and Tschopp, J. (2002). The inflammasome: a molecular platform triggering activation of inflammatory caspases and processing of proIL1ß. Mol. Cell 10, 417-426. doi: 10.1016/S1097-2765(02)00599-3

Masuda, T., Nishimoto, N., Tomiyama, D., Matsuda, T., Tozaki-Saitoh, H., Tamura, T., et al. (2014). IRF8 is a transcriptional determinant for microglial motility. Purinergic Signal. doi: 10.1007/s11302-014-9413-8. [Epub ahead of print].

Matos, M., Augusto, E., Agostinho, P., Cunha, R. A., and Chen, J. F. (2013). Antagonistic interactions between adenosine A2a receptors and $\mathrm{Na}^{+} / \mathrm{K}^{+}$-ATPase- $\alpha 2$ controlling glutamate uptake in astrocytes. J. Neurosci. 33, 18492-18502. doi: 10. 1523/JNEUROSCI.1828-13.2013

McLarnon, J. G., Ryu, J. K., Walker, D. G., and Choi, H. B. (2006). Upregulated expression of purinergic $\mathrm{P}_{2} \mathrm{X}_{7}$ receptor in Alzheimer disease and amyloid- $\beta$ peptide-treated microglia and in peptide-injected rat hippocampus. J. Neuropathol. Exp. Neurol. 65, 1090-1097. doi: 10.1097/01.jnen.0000240470. 97295.d3

Monif, M., Reid, C. A., Powell, K. L., Smart, M. L., and Williams, D. A. (2009). The P2X7 receptor drives microglial activation and proliferation: a trophic role for P2X7R pore. J. Neurosci. 29, 3781-3791. doi: 10.1523/JNEUROSCI.5512-08. 2009

Moore, D., Iritani, S., Chambers, J., and Emson, P. (2000). Immunohistochemical localization of the P2Y1 purinergic receptor in Alzheimer's disease. Neuroreport 11, 3799-3803. doi: 10.1097/00001756-200011270-00041

Morente, V., Perez-Sen, R., Ortega, F., Huerta-Cepas, J., Delicado, E. G., and MirasPortugal, M. T. (2014). Neuroprotection elicited by P2Y13 receptors against genotoxic stress by inducing DUSP2 expression and MAPK signalling recovery. Biochim. Biophys. Acta 1843, 1886-1898. doi: 10.1016/j.bbamcr.2014.05.004

Najjar, S., Pearlman, D. M., Alper, K., Najjar, A., and Devinsky, O. (2013). Neuroinflammation and psychiatric illness. J. Neuroinflammation 10:43. doi: 10 1186/1742-2094-10-43

Neher, J. J., Neniskyte, U., Hornik, T., and Brown, G. C. (2014). Inhibition of UDP/P2Y6 purinergic signalling prevents phagocytosis of viable neurons by activated microglia in vitro and in vivo. Glia 62, 1463-1475. doi: 10.1002/glia. 22693

Ni, J., Wang, P., Zhang, J., Chen, W., and Gu, L. (2013). Silencing of the P2X receptor enhances amyloid- $\beta$ phagocytosis by microglia. Biochem. Biophys. Res. Comm. 434, 363-369. doi: 10.1016/j.bbrc.2013.03.079

Noguchi, Y., Shinozaki, Y., Fujishita, K., Shibata, K., Imura, Y., Morizawa, Y., et al. (2013). Astrocytes protect neurons against methylmercury via ATP/P2Y(1) receptor-mediated pathways in astrocytes. PLoS One 8:e57898. doi: 10.1371/journal.pone.0057898

Noh, K. M., Hwang, J. Y., Follenzi, A., Athanasiadou, R., Miyawaki, T., Greally, J. M., et al. (2012). Repressor element-1 silencing transcription factor
(REST)-dependent epigenetic remodelling is critical to ischemia-induced neuronal death. Proc. Natl. Acad. Sci. U S A 109, E962-E971. doi: 10.1073/pnas. 1121568109

North, R. A., and Jarvis, M. F. (2013). P2X receptors as drug targets. Mol. Pharmacol. 83, 759-769. doi: 10.1124/mol.112.083758

Ogata, T., Chuai, M., Morino, T., Yamamoto, H., Nakamura, Y., and Schubert, P. (2003). Adenosine triphosphate inhibits cytokine release from lipopolysaccharide-activated microglia via P2y receptors. Brain Res. 981, 174 183. doi: 10.1016/s0006-8993(03)03028-2

Ohnishi, T., Matsumura, S., and Ito, S. (2009). Translocation of neuronal nitric oxide synthase to the plasma membrane by ATP is mediated by $\mathrm{P} 2 \mathrm{X}$ and $\mathrm{P} 2 \mathrm{Y}$ receptors. Mol. Pain 5:40. doi: 10.1186/1744-8069-5-40

Ohsawa, K., Sanagi, T., Nakamura, Y., Suzuki, E., Inoue, K., and Kohsaka, S. (2012). Adenosine A3 receptor is involved in ADP-induced microglial process extension and migration. J. Neurochem. 121, 217-227. doi: 10.1111/j.1471-4159. 2012.07693.x

Orr, A. G., Orr, A. L., Li, X. J., Gross, R. E., and Traynelis, S. F. (2009). Adenosine A(2A) receptor mediates microglial process retraction. Nat. Neurosci. 12, 872 878. doi: 10.1038/nn.2341

Pinhal-Enfield, G., Ramanathan, M., Hasko, G., Vogel, S. N., Salzman, A. L., Boons, G. J., et al. (2003). An angiogenic switch in macrophages involving synergy between Toll-like receptors 2, 4, 7 and 9 and adenosine A(2A) receptors. Am. J. Pathol. 163, 711-721. doi: 10.1016/s0002-9440(10)63698-x

Pons, V., Serhan, N., Gayral, S., Malaval, C., Nauze, M., Malet, N., et al. (2014) Role of the ubiquitin-proteasome system in the regulation of P2Y13 receptor expression: impact on hepatic HDL uptake. Cell. Mol. Life Sci. 71, 1775-1788. doi: 10.1007/s00018-013-1471-5

Purkayastha, S., and Cai, D. (2013). Neuroinflammatory basis of metabolic syndrome. Mol. Metab. 2, 356-363. doi: 10.1016/j.molmet.2013.09.005

Qureshi, I. A., and Mehler, M. F. (2013). Epigenetic mechanisms governing the process of neurodegeneration. Mol. Aspects Med. 34, 875-882. doi: 10.1016/j. mam.2012.06.011

Ren, H., and Stiles, G. H. (1994). Posttranscriptional mRNA processing as a mechanism for regulation of human Al adenosine receptor expression. Proc. Natl. Acad. Sci. U S A 91, 4864-4866. doi: 10.1073/pnas.91.11.4864

Robinson, L. E., and Murrell-Lagnado, R. D. (2013). The trafficking and targeting of P2X receptors. Front. Cell. Neurosci. 7:233. doi: 10.3389/fncel.2013.00233

Sanz, J. M., Chiozzi, P., Ferrari, D., Colaianna, M., Idzko, M., Falzoni, S., et al. (2009). Activation of microglia by amyloid beta requires P2X7 receptor expression. J. Immunol. 182, 4378-4385. doi: 10.4049/jimmunol.0803612

Serrano, A., Mo, G., Grant, R., Pare, M., O’Donnell, D., Yu, X. H., et al. (2012). Differential expression and pharmacology of native $\mathrm{P} 2 \mathrm{X}$ receptors in rat and primate sensory neurons. J. Neurosci. 32, 11890-11896. doi: 10.1523/JNEUROSCI. 0698-12.2012

Shaw, G., and Kamen, R. (1986). A conserved AU sequence from the $3^{\prime}$ untranslated region of GM-CSF mRNA mediates selective mRNA degradation. Cell 46, 659667. doi: 10.1016/0092-8674(86)90341-7

Shieh, C.-H., Heinrich, A., Serchov, T., van Calker, D., and Biber, K. (2014). P2X7dependent, but differentially regulated release of IL-6, CCL-2 and TNF- $\alpha$ in cultured mouse microglia. Glia 62, 592-607. doi: 10.1002/glia.22628

Solle, M., Labasi, J., Perregaux, D. G., Stam, E., Petrushova, N., Koller, B. H., et al. (2001). Altered cytokine production in mice lacking P2X7 receptors. J. Biol. Chem. 276, 125-132. doi: 10.1074/jbc.m006781200

Suzuki, T., Hide, I., Ido, K., Kohsaka, S., Inoue, K., and Nakata, Y. (2004). Production and release of neuroprotective tumour necrosis factor by $\mathrm{P}_{2} \mathrm{X}_{7}$ receptoractivated microglia. J. Neurosci. 24, 1-7. doi: 10.1523/jneurosci.3792-03.2004

Szekely, C. A., and Zandi, P. P. (2010). Non-steroidal anti-inflammatory drugs and Alzheimer's disease: the epidemiological evidence. CNS Neurol. Disord. Drug Targets 9, 132-139. doi: 10.2174/187152710791012026

Takenouchi, T., Nakai, M., Iwamaru, Y., Sugama, S., Tsukimoto, M., Fujita, M., et al. (2009). The activation of P2X7 receptor impairs lysosomal functions and stimulates the release of autophagolysosomes in microglial cells. J. Immunol. 182, 2051-2062. doi: 10.4049/jimmunol.0802577

Tanabe, T., and Tohnai, N. (2002). Cyclooxygenase isoenzymes and their gene structures and expression. Prostaglandins Other Lipid Mediat. 68-69, 95-114. doi: 10.1016/s0090-6980(02)00024-2

Threlfell, S., Lalic, T., Platt, N. J., Jennings, K. A., Diesseroth, K., and Cragg, S. J. (2012). Striatal dopamine release is triggered by synchronized activity in cholinergic interneurons. Neuron 75, 58-64. doi: 10.1016/j.neuron.2012.04.038 
Ulmann, L., Hirbec, C., and Rassendren, F. (2010). P2X4 receptors mediate PGE2 release by tissue-resident macrophages and initiate inflammatory pain. EMBO J. 29, 2290-2300. doi: 10.1038/emboj.2010.126

Ulrich, H., Abbracchio, M. P., and Burnstock, G. (2012). Extrinsic purinergic regulation of neural stem/progenitor cells: implications for CNS development and repair. Stem Cell Rev. 8, 755-767. doi: 10.1007/s12015-0129372-9

Varani, K., Vincenzi, F., Tosi, A., Gessi, S., Casetta, I., Granieri, G., et al. (2010). A2A adenosine receptor overexpression and functionality, as well as TNF- $\alpha$ levels, correlate with motor symptoms in Parkinson's disease. FASEB J. 24, 587-598. doi: 10.1096/fj.09-141044

Varma, R., Chai, Y., Troncoso, J., Gu, J., Xing, H., Stojilkovic, S., et al. (2009). Amyloid- $\beta$ induces a caspase-mediated cleavage of P2X4 to promote purinotoxicity. Neuromol. Med. 11, 63-75. doi: 10.1007/s12017-009-8073-2

Verderio, C., and Matteoli, M. (2001). ATP mediates calcium signalling between astrocytes and microglial cells: modulation by IFN- $\gamma$. J. Immunol. 166, 63836391. doi: 10.4049/jimmunol.166.10.6383

Viscomi, M. T., Florenzano, F., Conversi, D., Bernardi, G., and Molinari, M. (2004). Axotomy dependent purinergic and nitrergenic co-expression. Neuroscience 123, 393-404. doi: 10.1016/j.neuroscience.2003.09.030

Walker, D. G., Link, J., Lue, L.-F., Dalsing-Hernandez, J. E., and Boyes, B. E. (2006). Gene expression changes by amyloid beta peptide-stimulated human post-mortem brain microglia identify activation of multiple inflammatory processes. J. Leukoc. Biol. 79, 596-610. doi: 10.1189/jlb.0705377

Wang, L., Olivecrona, G., Gotberg, M., Olsson, M. L., Winzell, M. S., and Erlinge, D. (2005). ADP acting on P2Y13 receptors is a negative feedback pathway for ATP release from human red blood cells. Circ. Res. 96, 189-196. doi: 10.1161/01. res.0000153670.07559.e4

Webster, C. M., Hokari, M., McManus, A., Tang, X. N., Ma, H., Kacimi, R., et al. (2013). Microglial P2Y12 deficiency/inhibition protects against brain ischemia. PLoS One 8:e70927. doi: 10.1371/journal.pone.0070927

Whiteside, T. L., and Jackson, E. K. (2013). Adenosine and prostaglandin $\mathrm{E}_{2}$ production by human inducible regulatory $\mathrm{T}$ cells in health and disease. Front. Immunol. 4:212. doi: 10.3389/fimmu.2013.00212

Xanthos, D. N., and Sandkuhler, J. (2014). Neurogenic neuroinflammation: inflammatory CNS reactions in response to neuronal activity. Nat. Rev. Neurosci. 15, 43-53. doi: 10.1038/nrn3617
Xia, M., and Zhu, Y. (2011). Signaling pathways of ATP-induced PGE 2 release in spinal cord astrocytes are EGFR transactivation-dependent. Glia 59, 664-674. doi: 10.1002/glia.21138

Xu, J., Chalimoniuk, M., Shu, Y., Simonyi, A., Sun, A. Y., Gonzalez, F. A., et al. (2003). Prostaglandin $E_{2}$ production in astrocytes: regulation by cytokines, extracellular ATP, oxidative agents. Prostaglandins Leukot. Essent. Fatty Acids 69, 437-448. doi: 10.1016/j.plefa.2003.08.016

Yedgar, S., Krimsky, M., Cohen, Y., and Flower, R. J. (2007). Treatment of inflammatory diseases by selective eicosanoid inhibition: a double-edged sword? Trends Pharmacol. Sci. 28, 459-464. doi: 10.1016/j.tips.2007.07.005

Yoshida, Y., Yoshimi, R., Yoshii, Y., Kim, D., Dey, A., Xiong, H., et al. (2014). The transcription factor IRF8 activates integrin-mediated TGF- $\beta$ signalling and promotes neuroinflammation. Immunity 40, 187-198. doi: 10.1016/j.immuni. 2013.11.022

Young, L. E., Moore, A. E., Sokol, L., Meisner-Kober, N., and Dixon, D. A. (2012). The mRNA stability factor HuR inhibits microRNA-16 targeting of COX-2. Mol. Cancer Res. 10, 167-180. doi: 10.1158/1541-7786.MCR-11-0337

Zheng, D., Worthington, J., Timms, J. F., and Woo, P. (2013). HNRNPA1 interacts with a 5'-flanking distal element of interleukin-6 and upregulates its basal transcription. Genes Immun. 14, 479-486. doi: 10.1038/gene.2013.41

Conflict of Interest Statement: The authors declare that the research was conducted in the absence of any commercial or financial relationships that could be construed as a potential conflict of interest.

Received: 30 June 2014; accepted: 14 August 2014; published online: 01 September 2014.

Citation: Fiebich BL, Akter S and Akundi RS (2014) The two-hit hypothesis for neuroinflammation: role of exogenous ATP in modulating inflammation in the brain. Front. Cell. Neurosci. 8:260. doi: 10.3389/fncel.2014.00260

This article was submitted to the journal Frontiers in Cellular Neuroscience.

Copyright (C) 2014 Fiebich, Akter and Akundi. This is an open-access article distributed under the terms of the Creative Commons Attribution License (CC BY). The use, distribution or reproduction in other forums is permitted, provided the original author(s) or licensor are credited and that the original publication in this journal is cited, in accordance with accepted academic practice. No use, distribution or reproduction is permitted which does not comply with these terms. 